UDC 342.95:349.6(474.5)

DOI https://doi.org/10.26661/hst-2021-8-85-11

\title{
LEGAL PROBLEMS OF LEGAL ENTITIES ' LIABILITY FOR DAMAGES TO THE ENVIRONMENT REGULATION
}

\author{
(C) PERKUMIENĖ, DALIA \\ E-mail: dalia.perkumiene@vdu.lt \\ ORCID iD: 0000-0003-4072-3898 \\ Vytautas Magnus University Agriculture Academy (Kaunas, Lithuania) \\ Studentu str. 11, Akademija, Kaunas district LT-53361 \\ (c) ČILINSKAITE், LAURA \\ E-mail: 1.cilinskaite@gmail.com \\ ORCID iD: https://orcid.org/0000-0002-1385-5775 \\ Kazimieras Simonavičius University Dariaus ir Girèno g. 21, Vilnius, Lithuania 02189
}

\begin{abstract}
Abstarct.
The relevance of this study. With the growing influence of legal entities, the financial power and the consumption needs of the population, the occurrence of environmental damage, human health and other values protected by legal acts are threatened accordingly. The constitutional bases for the protection of the natural environment, the use of its individual objects and the legal regulation of relations are enshrined in the provisions of, inter alia, Articles 47, 53 and 54 of the Constitution of the Republic of Lithuania. These two values enshrined in the Constitution and the jurisprudence interpreting its provisions raise the need to introduce a balance of rights and obligations into Lithuanian legal acts regulating economic activity and environmental protection, which would systematically and clearly ensure the balance of individual rights to a clean environment and freedom of economic activity. The legislator has a constitutional duty to regulate economic activity in such a way that it complies with universal values and performs such economic functions that satisfy the needs of society at the same time and do not harm the common good.

The main problem. The uncertainty and inconsistency legislation governing of all environmental legal relations and liability, the excessive abundance and the frequent conflict of their application and interpretation shape the complex implementation of the legal framework and the contradictory case law. With regard to the question of the legal liability of a legal person, there is no consensus and practice as to who should be held liable for the infringement committed and whether the application of double punishment, both to employees of legal persons and to the legal person itself, does not infringe the non bis in idem principle. The following tasks: 1 . To reveal the concept and social significance of legal regulation of liability of legal persons for environmental damage. 2. Evaluate the effectiveness and adequacy of the regulation of existing legislation in applying legal liability for environmental damage to legal persons. 3. To analyze the peculiarities of court practice related to the legal regulation of the liability of legal persons for environmental damage. The aim of this work to evaluate the effectiveness of legal regulation of legal persons' liability for environmental damage and the problems of its application. The paper concluded that one of the biggest problems causing various misunderstandings is the abundance of laws and regulations governing environmental relations and their extremely frequent changes. The legal acts that make up the regulation of environmental law are multi-level, there are a lot of laws and by-laws detailing them, as well as many institutions that follow and enforce them. This complicates the application of this legislation in both institutions and case law and hinders the effective implementation of environmental objectives by the state. The novelty Due to the extremely frequent changes in the laws and the possibilities of applying the liability of legal persons, which have been expanded in recent years, this topic has not been widely analyzed yet, especially in terms of administrative liability applied to legal persons. Also, due to the infrequent application of this institute of responsibility, there is little case law that would help to interpret the regulation of laws and the conditions of legality of practical application, so the analysis of the topic of this work will help to reveal and identify the main shortcomings of current regulation. As the result taking into account the specificities of all types of liability, the most effective form of liability for legal persons is administrative liability through economic sanctions, which is one of the most effective means of proportionate punishment in the most optimal time to deal with environmental damage and remedies. The used methodology document analysis, systematic analysis, comparative, logical-analytical method, and generalization methods. Keywords: legal entities, liability, environmental damage, and remedies.
\end{abstract}

Statement of the problem.

The uncertainty and inconsistency legislation governing of all environmental legal relations and liabil- ity, the excessive abundance and the frequent conflict of their application and interpretation shape the complex implementation of the legal frame-

Legal problems of legal entities ' liability for damages to the environment regulation 
work and the contradictory case law. With regard to the question of the legal liability of a legal person, there is no consensus and practice as to who should be held liable for the infringement committed and whether the application of double punishment, both to employees of legal persons and to the legal person itself, does not infringe the non bis in idem principle.

Relevance of the topic with the growing influence of legal entities, the financial power and the consumption needs of the population, the occurrence of environmental damage, human health and other values protected by legal acts are threatened accordingly. The constitutional bases for the protection of the natural environment, the use of its individual objects and the legal regulation of relations are enshrined in the provisions of, inter alia, Articles 47, 53 and 54 of the Constitution of the Republic of Lithuania. These two values enshrined in the Constitution and the jurisprudence interpreting its provisions raise the need to introduce a balance of rights and obligations into Lithuanian legal acts regulating economic activity and environmental protection, which would systematically and clearly ensure the balance of individual rights to a clean environment and freedom of economic activity. The legislator has a constitutional duty to regulate economic activity in such a way that it complies with universal values and performs such economic functions that satisfy the needs of society at the same time and do not harm the common good.

The aim of the research is to evaluate the effectiveness of legal regulation of legal persons' liability for environmental damage and the problems of its application.

\section{Results.}

In the current time, the concept of liability of legal entities for environmental impacts has changed significantly compared to the stage of economic development when plants and polluting companies were not so limited and the public did not look against it because environmental damage was less severe and economic development was paramount. priority. Modern society is setting ever higher environmental standards and socially responsible companies are gaining more and more favor by pursuing not only economic but also social and environmental positive change. The Constitutional Court of the Republic of Lithuania notes that "one of the objectives of the state is to ensure people's rights to a healthy and clean environment", therefore on this basis the state implements the constitutional duty to ensure nature conservation balance of duties, the breach of which gives rise to legal liability in response to the damage suffered [1].

Legal responsibility is one of the types of social responsibility, so to live in harmony with the communities to which it belongs, individuals must adhere to commonly accepted norms and principles, because the well-being of themselves and others depends on it. The concept of legal responsibility derives from the legal self-awareness of the society because it is based only on the ability of the society to exercise its subjective rights and the performance of the assumed obligations [2]. According to A. Vaišvila, legal liability is a process that manifests itself in the obligation to refrain from an act dangerous to society and the obligation to compensate for damage if it occurs. Thus, the level of public awareness also affects the way the environment is treated, the attitude towards the conservation and use of its resources, and the public's response to environmental damage incidents and global climate change [3].

The concept, principles, and types of legal liability of legal persons for environmental damage

It is important to delve into the concept of legal entities' liability for environmental damage and the mechanism of operation. The issue of the essence of legal persons is more examined in civil law, but in recent decades the bases of their liability have been introduced in Lithuania into the norms of administrative and criminal law, seeing that civil liability alone is not enough to compensate not only private interest but also public interest. damage - damage caused by environmental violations. Legal entities that carry out economic activities are subject to stricter requirements and higher sanctions on the grounds that they are often managers of higher-risk facilities and are presumed to have more knowledge of the risks they assume and the rights they exercise during their economic activities. Also, their activities are more likely to have larger-scale negative consequences than the activities of individuals. According to E. Monkevičius, the object of regulation of environmental law is "public protection and improvement of the quality of the natural environment, safe existence and sustainable development of society and every person, economical and rational use and restoration of natural resources, prevention of environmental violations, liability and environmental compensation, public and the relationship between the protection of private interests as well as the implementation of cross-border environmental measures [4]. " The concept of an environmental object includes the mul- 
tilateral nature of the environment, which aims at reconciling economic, social, and environmental interests. Such an interpretation of the object contrasts with the narrower provision of the object of environmental law enshrined in Article 3 of the EPL, stating that it is the totality of interrelated elements functioning in nature in the Republic of Lithuania and the natural and anthropogenic systems uniting them [5].

Environmental protection rights set out in international legal acts and the main law of the Republic of Lithuania - the Constitution - are the basis for creating strategic goals and issuing legal acts. They shape the main directions of sustainable development and environmental protection. The basic principles of environmental protection enshrined in EU legislation are eco-efficiency, pollution prevention, source of harm, integration of environmental policies, precaution, public participation and information, responsibility ("polluter pays"), partnership and responsibility-sharing [6]. These environmental principles are singled out as key ones that have had a significant impact on the drafting and adoption of legislation at international, regional and national levels. International environmental law also uses the intergenerational principle, which describes the right of each generation to use natural resources to meet the needs and the obligation to pass them on to future generations without deteriorating the state of the environment, i. take responsibility for maintaining the current state of environmental quality [7]. The above principles are also valid in the Lithuanian legal system and are incorporated into laws.

In case of violation of environmental law, legal persons may be prosecuted, administratively or civilly, depending on the nature of the environmental pollution violation, the nature and degree of its danger. Civil liability is applied together with criminal or administrative proceedings when the violation of the law has caused damage to the environment and non-contractual liability. An obligation then arises for the legal person to take all measures to repair the damage caused, i. to apply the principle of restitutio in integrum and to compensate for the damage caused to the environment in accordance with the calculated methodology for compensation and calculation of environmental damage published by the Minister [8].

Legal persons assume responsibility and obligation to implement certain obligations for the right to exercise their rights to the realization and development of economic activities. As legal entities, they must comply with the applicable legal norms, without prejudice to the environmental requirements imposed on them, beyond which they would incur liability.

Effectiveness of the regulation of liability of legal persons for environmental damage and problems in court practice.

Environmental litigation is one of the most significant areas of dispute, as the current practice of resolving these disputes can have a significant impact on shaping the quality of life of future generations as well. One of the main environmental goals is to preserve a healthy environment for future generations, on which basis legislation regulates nature protection and conservation. One of the most common problems in the judicial practice of legal persons is the emergence of the constitutional principle non bis in idem (the same violation of the law cannot be punished twice) by receiving several fines for the same violation. The essence of this principle is to avoid disproportionate punishment, but it is not prohibited to distinguish between different types of liability that are imposed after punishment. The problem of punishment arises when there is a risk of double punishment with the same type of liability, which often occurs when authorized environmental officers impose a sanction on both the legal entity and those responsible for that legal entity, so it is important to properly analyze their delimitation.

Chamber of Judges of the Supreme Administrative Court of Lithuania in 2020 January 29 made an order in an administrative case regarding the annulment of decisions imposing economic sanctions on a legal person. The head of UAB Super Montes was held administratively liable for non-compliance with the mandatory instructions in accordance with Article 317 (2) of the ANC and fined, but the Department for the same violation - non-compliance with the mandatory instructions to dispose of waste illegally stored demolition waste stored in a place not specified in the scheme, from an illegally stored place, also imposed a fine on the legal entity itself in accordance with Article 126 AAA. The applicant UAB Super Montes challenged the two economic sanctions adopted for the same violation, one of which was imposed on the head of the legal entity and the other on the legal entity itself, claiming that it violated the constitutional principle of non bis in idem [9].

Another important aspect is the issue of delimitation of liability. The assessment of liability for environmental damage depends primarily on the extent, extent and consequences of the environmental damage. It is the question of the consequences of an infringement that is one of the most difficult, as it 
is for professionals who can assess the damage caused to the environment to prove it. The burden of proof on public authorities, as defenders of the public interest, in investigating damage is often based on the distribution of public resources, which is unfortunately rather limited due to insufficient state funding and a lack of specialists. This also determines the court's own decisions in demarcating administrative and criminal liability and determining the amount of damage. Extended Chamber of Judges of the Criminal Cases Division of the SCL in 2020 April 20 passed a ruling in a criminal case [10] in which the landowner was accused of transforming part of the wetland into water, i.e., by excavating a tractor with a tractor. $y$. turned part of the former wetland on its plot into land occupied by surface water bodies, and at the same time mechanically dismantled the vegetation cover of 0.8248 ha of this natural wetland, thus causing EUR 113,245.04 damage to nature. This damage was calculated in accordance with the Methodology for Calculating Environmental Damage from Destruction or Damage of Natural Landscape Complexes and Objects approved by the Minister of Environment of the Republic of Lithuania in 2014. March 12 by order no. D1-269 “On Approval of the Methodology for Calculating Environmental Damage Due to Destruction or Damage of Natural Landscape Complexes and Objects". In its ruling, the panel of judges relied on the case law of the Court of Cassation that the objective feature of a criminal offense provided for in Article 270 (2) of the CC significant damage to air, land, water, animals or plants or other serious consequences for the environment the seriousness of the infringement. The panel of judges noted that the nature of the breach of environmental rules, the extent of material damage, the nature and extent of the damage to the ecosystem, the nature of the damage to nature, the value of the objects that have been damaged, the extent of the damage, the ability to recover what has been destroyed, damaged, and so on [11]. The Court of Cassation concluded that the amount of material damage calculated in accordance with that methodology could not be the sole criterion for determining serious damage. A necessary element of the objective side of the aggravated crime established in Article 270 (2) of the CC is the real consequences, which presupposes not only the assessment of the actual damage, but also the necessity to identify the specific environmental component that has been harmed. Significant damage occurs when an object specially protected by the state is destroyed or severely dam- aged, or significant material damage is caused to it, which is an evaluative feature of the crime, the content of which is revealed by assessing the specific facts of the case [12]. The Court of Cassation concluded that the sign of serious damage had not been established in the present case and that the serious damage to the environment had been determined solely based on the amount of material damage calculated according to the methodology, contrary to the examples of cassation practice above.

In the EU, one of the most prominent ecological issues of many years of debate and conflict between countries has been over the pollution of the Rhine with various chemicals. Pollution levels in the rivers bordering Switzerland, Germany, France, Luxembourg, and the Netherlands rose as early as the early twentieth century with the Industrial Revolution, which led to significant biodiversity loss, declining water quality, increased flooding, and a gradual threat to the Rhine ecosystem. The Netherlands, as the country most affected by the pollution of the Rhine, initiated the International Commission for the Protection of the Rhine against Pollution in June 1950, together with Switzerland, Germany, France, and Luxembourg. This commission delved into the problem, but no substantive liability mechanisms were in place until 1986, when a major accident spilled about 20 tons of chemicals into the Rhine that caused significant damage to the river's ecosystems. Criminal liability was taken against those responsible for the accident, together with compensation to the states for the damage, but the dispute was settled amicably, so no case law was established as a legal basis for future similar cases. Thus, at a time when the main environmental liability directives have not yet been adopted, priority has been given to alternative dispute resolution and the development of a river ecosystem recovery plan [13]. In actions for damages, questions of jurisdiction must be determined in relation to the State in which the case is to be heard and the question of the application of the law to be followed must be chosen. It must also be ascertained whether the judgments given will be enforced and recognized under the law of that place. Jurisdiction is governed by the Brussels I Regulation, which allows for the choice of three parties, depending on the defendant's place of registration, the place where the damage occurred or the place where the accident took place [14]. As regards the application of the law, in accordance with Article 4 of the Rome II Regulation, non-contractual liability is governed by the law of the country in which the party was harmed, regard- 
less of the location of the accident [15]. Therefore, the State and its responsible authorities, as the main defender of the public interest, may bring actions for environmental damage against other responsible parties in accordance with these regulations.

\section{Conclusion:}

1. Civil liability applicable to legal persons arises from damage to the environment caused by their economic activities, which is calculated in accordance with the methodologies of the Minister of the Environment. The primary function of this liability is to compensate for the damage caused to the environment or, if you choose to apply a plan of remedial measures, to remedy it.

2. Criminal liability of legal persons shall be the most severe form of liability applicable only to very serious crimes or criminal offenses against the environment and human health. This type of liability is the most difficult to prove, as sufficient evidence must be gathered to substantiate all the conditions of criminal liability.

3. State resources to investigate environmental damage by assessing the totality of circumstances - the initial condition and its change and the consequences of damage, are not sufficient to accurately calculate the amount of damage and assess the extent of the consequences.

4. Environmental control officers supervising the activities of economic operators have a wide range of statutory powers to impose sanctions, but the complicated determination of environmental damage lacks the appropriate tools and the ability to apply and use them due to a lack of necessary evidence.

\section{Список використаних джерел}

1. 2006 of the Constitutional Court of the Republic of Lithuania March 14 ruling in case no. 17 / 02-24 / 02-06 / 03-22 / 04. Internet access: https://www.lrkt.lt/lt/teismo-aktai/paieska/135/ta198/content [accessed 10 February 2021].

2. Prapiestis, J., et al. (2002). Home Attorney. Vilnius: Legal Information Center, p. 871.

3. Vaišvila, A. (2002). Theory of law. Vilnius: Justitia. p. $349-365$.

4. Monkevičius, E. Problems of compensation for environmental damage. Lecture course. Internet access: http:// edumon.lt/wp-content/uploads/2014/02/ZALOS_APLINKAI_ATLYGINIMO_PROBLEMOS_Paskaitu_kursas.pdf, [accessed 12 January 2021].

5. Law of the Republic of Lithuania on Environmental Protection (No. 5-75 of 21 January 1992) New wording, TAR, 01/01/2021 - 30/04/2021, No. 20-0.

6. Resolution of the Seimas of the Republic of Lithuania in 2015 April 16 No. XII-1626 "On the Approval of the National Environmental Protection Strategy" TAR, 2015-04-24, No. 6178.

7. Report of the Secretary-General, 5 August 2013 Intergenerational solidarity and the needs of future generations. Internet access: https://sustainabledevelopment.un.org/content/documents/2006future.pdf [accessed 18/02/2021].

8. Minister of Environment of the Republic of Lithuania, 2002 September 9 order no. 471 "On the Approval of the Methodology for Calculating the Amounts of Compensation for Environmental Damage", New Edition, TAR, 01.07.2018, no. $93-4026$.

9. Judges of the Supreme Administrative Court of Lithuania in 2020 January 29 order in case no. EA-55-525 / 2020 Internet access: https://e-teismai.lt/byla/60199056545977/eA-55-525/2020 [accessed 28/04/2021].

10. Judges of the Criminal Cases Division of the Supreme Court of Lithuania in 2020 April 20 order in case no. 2K-7-57-489/2020. Internet access: https://eteismai.lt/byla/237827830711726/2K-7-57-489/2020 [accessed 0707 2021].

11. The panel of judges of the Criminal Cases Division of the Supreme Court of Lithuania in 2018. May 15 order in case no. 2K-169-689 / 2018. Internet access: https://eteismai.lt/byla/254825893174924/2K-169-689/2018 [accessed on 09/03/2021].

12. The panel of judges of the Criminal Cases Division of the Supreme Court of Lithuania in 2015 March 3 order in case no. 2K-155-693 / 2015 Internet access: https://eteismai.lt/byla/70419132574925/2K-155-693/2015 [accessed on 09/03/2021].

13. Leb C. The International Commission for the Protection of the Rhine. IUCN case studies. Internetinis leidinys. Internet access: https://www.iucn.org/sites/dev/files/import/downloads/rhine.pdf p. 2 [accessed 202104 20].

14. Krstinić D., Bingulac N., Dragojlović J. Criminal and civil liability for environmental damage. Ekonomika poljoprivrede. 2017. 64(3):1161-1176. Internet access: https://www.researchgate.net/publication/322090086_Criminal_ and_civil_liability_for_environmental_damage p. 1168 [accessed 202104 18].

15. 2007 July 31 Regulation (EC) No 1/2003 of the European Parliament and of the Council 864/2007 on the law applicable to non-contractual obligations (Rome II), Internet access: https://eur-lex.europa.eu/legal-content/EN/ ALL/?uri=CELEX:32007R0864 [accessed 14 April 2021].

Legal problems of legal entities ' liability for damages to the environment regulation 


\section{References}

1.2006 of the Constitutional Court of the Republic of Lithuania March 14 ruling in case no. 17 / 02-24 / 02-06 / 03-22 / 04. Internet access: https://www.lrkt.lt/lt/teismo-aktai/paieska/135/ta198/content [accessed 10 February 2021].

2. Prapiestis, J., et al. (2002). Home Attorney. Vilnius: Legal Information Center, p. 871.

3. Vaišvila, A. (2002). Theory of law. Vilnius: Justitia. p. 349 - 365.

4. Monkevičius, E. Problems of compensation for environmental damage. Lecture course. Internet access: http://edumon.lt/wp-content/uploads/2014/02/ZALOS_APLINKAI_ATLYGINIMO_PROBLEMOS_ Paskaitu_kursas.pdf, [accessed 12 January 2021].

5. Law of the Republic of Lithuania on Environmental Protection (No. 5-75 of 21 January 1992) New wording, TAR, 01/01/2021 - 30/04/2021, No. 20-0.

6. Resolution of the Seimas of the Republic of Lithuania in 2015 April 16 No. XII-1626 "On the Approval of the National Environmental Protection Strategy" TAR, 2015-04-24, No. 6178.

7. Report of the Secretary-General, 5 August 2013 Intergenerational solidarity and the needs of future generations. Internet access: https://sustainabledevelopment.un.org/content/documents/2006future.pdf [accessed $18 / 02 / 2021]$.

8. Minister of Environment of the Republic of Lithuania, 2002 September 9 order no. 471 "On the Approval of the Methodology for Calculating the Amounts of Compensation for Environmental Damage", New Edition, TAR, 01.07.2018, no. 93-4026.

9. Judges of the Supreme Administrative Court of Lithuania in 2020 January 29 order in case no. EA-55525 / 2020 Internet access: https:/e-teismai.lt/byla/60199056545977/eA-55-525/2020 [accessed 28/04/2021].

10. Judges of the Criminal Cases Division of the Supreme Court of Lithuania in 2020 April 20 order in case no. 2K-7-57-489 / 2020. Internet access: https://eteismai.lt/byla/237827830711726/2K-7-57-489/2020 [accessed $07072021]$.

11. The panel of judges of the Criminal Cases Division of the Supreme Court of Lithuania in 2018. May 15 order in case no. 2K-169-689 / 2018. Internet access: https://eteismai.lt/byla/254825893174924 /2K-169-689/2018 [accessed on 09/03/2021].

12. The panel of judges of the Criminal Cases Division of the Supreme Court of Lithuania in 2015 March 3 order in case no. 2K-155-693 / 2015 Internet access: https://eteismai.lt/byla/70419132574925 /2K-155-693/2015 [accessed on 09/03/2021].

13. Leb C. The International Commission for the Protection of the Rhine. IUCN case studies. Internetinis leidinys. Internet access: https://www.iucn.org/sites/dev/files/import/downloads/rhine.pdf p. 2 [accessed $20210420]$.

14. Krstinić D., Bingulac N., Dragojlović J. Criminal and civil liability for environmental damage. Ekonomika poljoprivrede. 2017. 64(3):1161-1176. Internet access: https://www.researchgate.net/publication/322090086_Criminal_and_civil_liability_for_environmental_damage p. 1168 [accessed 20210418 ].

15. 2007 July 31 Regulation (EC) No 1/2003 of the European Parliament and of the Council 864/2007 on the law applicable to non-contractual obligations (Rome II), Internet access: https://eur-lex.europa.eu/legal-content/EN/ALL/?uri=CELEX:32007R0864 [accessed 14 April 2021].

ПЯРКУМЕНЕ, ДАЛЯ - Доц. проф. Доктор юридичних наук, Університет Вітаутаса Великого (Каунас, Литва)

E-mail: dalia.perkumiene@vdu.lt

ORCID: 0000-0003-4072-3898

ЧІЛІНСКАЙТЕ, ЛАУРА - Магістр права, Університет імени Казиміраса Симонавічуса (Вільнюс, Литва)

E-mail: 1.cilinskaite@gmail.com

ORCID: 0000-0002-1385-5775 


\section{ПРАВОВІ ПРОБЛЕМИ ВІДПОВІДАЛЬНОСТІ ЮРИДИЧНИХ ОСІБ ЗА ЗБИТКИ ЕКОЛОГІЧНИХ НОРМ}

\section{Анотація.}

Актуальність дослідження. 3 ростом впливу юридичних осіб фінансова міць і споживчі потреби населення, заподіяння шкоди навколишньому природному середовищу, здоров'ю людини та інших цінностей, що охороняються правовими актами, відповідно знаходяться під загрозою. Конституційні основи захисту навколишнього природного середовища, використання іï окремих об'єктів і правового регулювання відносин закріплені, зокрема, у положеннях статей 47, 53 і 54 Конституції Литовської Республіки. Ці дві цінності, закріплені в Конституції, і судова практика, що інтерпретує ці положення, викликають необхідність введення балансу прав і обов'язків у литовські правові акти, що регулюють економічну діяльність і охорону навколишнього середовища, що систематично і чітко забезпечувало б баланс індивідуальних прав на чисте довкілля та свободу господарської діяльності. Законодавець має конституційний обов'язок регулювати економічну діяльність таким чином, щоб вона відповідала універсальним цінностям і виконувала такі економічні функції, які одночасно задовольняють потреби суспільства і не завдають шкоди загальному благу. Головна проблема. Невизначеність і непослідовність законодавства, що регулюють всі екологічні правовідносини і відповідальність, надмірнй достаток і часті конфлікти їх застосування та тлумачення визначають складну реалізацію правової бази і суперечливу судову практику. Що стосується питання про юридичну відповідальність юридичної особи, то немає консенсусу і практики щодо того, хто повинен нести відповідальність за вчинене порушення та чи слід застосовувати подвійне покарання, як до співробітників юридичних осіб, так і до юридичних осіб. Сам по собі не порушує принцип non bis in idem. Вирішені наступні завдання: 1. Розкрити поняття і соціальну значимість правового регулювання відповідальності юридичних осіб за екологічні збитки. 2. Оцінити ефективність і адекватність регулювання чинного законодавства при застосуванні юридичної відповідальності за екологічні збитки до юридичних осіб. 3. Проаналізувати особливості судової практики щодо правового регулювання відповідальності юридичних осіб за заподіяння шкоди навколишньому середовищу. Мета роботи Оцінити ефективність правового регулювання відповідальності юридичних осіб за заподіяння шкоди навколишньому середовищу і проблеми його застосування. У статі зроблено висновок, що одна $з$ найбільших проблем, яка викликає різні непорозуміння, - це велика кількість законів і постанов, що регулюють екологічні відносини, та їх надзвичайно часті зміни. Правові акти, що становлять регулювання екологічного права, $є$ багаторівневими, існує безліч законів та підзаконних актів, що деталізують їх, а також безліч інститутів, які стежать за ними і забезпечують їх дотримання. Це ускладнює застосування цього законодавства як в інститутах, так і в судовій практиці, і перешкоджає ефективному здійсненню державою екологічних цілей. Новизна дослідження у зв'язку з надзвичайно частими змінами у законодавстві і можливостями застосування відповідальності юридичних осіб, яка розширилася за останні роки, і ця тема ще не отримала широкого аналізу, особливо в частині адміністративної відповідальності, яка застосовується до юридичних осіб. Також через несистематичне застосування цього інституту відповідальності мало прецедентного права, яке допомогло б інтерпретувати норму законів і умови законності практичного застосування. Тому аналіз теми даної роботи допоможе виявити і виявити основні недоліки чинного регулювання. В результаті аналізу, з огляду на специфіку всіх видів відповідальності, найбільш ефективною формою відповідальності для юридичних осіб $є$ адміністративна відповідальність у вигляді економічних санкцій, що $є$ одним з найбільш ефективних засобів відповідного покарання у найбільш оптимальні строки для вирішення екологічних проблем, збиток і засоби правового захисту. Використана методологія - аналіз документів, системний аналіз, порівняльний, логіко-аналітичний метод і методи узагальнення.

Ключові слова: юридичні особи, відповідальність, екологічний збиток і засоби правового захисту.

ПЯРКУМЕНЕ, ДАЛЯ - Доц. проф. Доктор юридических наук. Университет Витаутаса Великого (Каунас, Литва)

E-mail: dalia.perkumiene@vdu.1t

ORCID: 0000-0003-4072-3898

ЧИЛИНСКАЙТЕ, ЛАУРА - Магистр права, Университет имени Казимираса Симонавичуса (Вильнюс, Литва)

E-mail:1.cilinskaite@gmail.com

ORCID: 0000-0002-1385-5775

Legal problems of legal entities ' liability for damages to the environment regulation 


\title{
ПРАВОВЫЕ ПРОБЛЕМЫ ОТВЕТСТВЕННОСТИ ЮРИДИЧЕСКИХ ЛИЦ ЗА УБЫТКИ ЭКОЛОГИЧЕСКИХ НОРМ
}

\begin{abstract}
Аннотация.
Актуальность исследования. С ростом влияния юридических лиц финансовая мощь и потребительские потребности населения, причинение ущерба окружающей среде, здоровью человека и другим ценностям, охраняемым правовыми актами, соответственно находятся под угрозой. Конституционные основы защиты окружающей природной среды, использования ее отдельных объектов и правового регулирования отношений закреплены, в частности, в положениях статей 47, 53 и 54 Конституции Литовской Республики. Эти две ценности, закрепленные в Конституции, и судебная практика, интерпретирующая ее положения, вызывают необходимость введения баланса прав и обязанностей в литовские правовые акты, регулирующие экономическую деятельность и охрану окружающей среды, что систематически и четко обеспечивало бы баланс индивидуальных прав на чистая окружающая среда и свобода хозяйственной деятельности. Законодатель имеет конституционную обязанность регулировать экономическую деятельность таким образом, чтобы она соответствовала универсальным ценностям и выполняла такие экономические функции, которые одновременно удовлетворяют потребности общества и не наносят вреда общему благу. Главная проблема. Неопределенность и непоследовательность законодательства, регулирующего все экологические правоотношения и ответственность, чрезмерное изобилие и частые конфликты их применения и толкования определяют сложную реализацию правовой базы и противоречивую судебную практику. Что касается вопроса о юридической ответственности юридического лица, то нет консенсуса и практики относительно того, кто должен нести ответственность за совершенное нарушение и следует ли применять двойное наказание, как к сотрудникам юридических лиц, так и к юридическим лицам. сам по себе не нарушает принцип non bis in idem. Решены следующие задачи: 1. Раскрыть понятие и социальную значимость правового регулирования ответственности юридических лиц за экологический ущерб. 2. Оценить эффективность и адекватность регулирования действующего законодательства при применении юридической ответственности за экологический ущерб к юридическим лицам. 3. Проанализировать особенности судебной практики по правовому регулированию ответственности юридических лиц за причинение вреда окружающей среде. Цель работы Оценить эффективность правового регулирования ответственности юридических лиц за причинение вреда окружающей среде и проблемы его применения. В документе сделан вывод, что одна из самых больших проблем, вызывающих различные недоразумения, - это обилие законов и постановлений, регулирующих экологические отношения, и их чрезвычайно частые изменения. Правовые акты, составляющие регулирование экологического права, являются многоуровневыми, существует множество законов и подзаконных актов, детализирующих их, а также множество институтов, которые следят за ними и обеспечивают их соблюдение. Это усложняет применение этого законодательства как в институтах, так и в судебной практике, и препятствует эффективному осуществлению государством экологических целей. Новизна в связи с чрезвычайно частыми изменениями в законодательстве и возможностями применения ответственности юридических лиц, которая расширилась в последние годы, эта тема еще не получила широкого анализа, особенно в части административной ответственности, применяемой к юридическим лицам. Также из-за нечастого применения этого института ответственности мало прецедентного права, которое помогло бы интерпретировать норму законов и условия законности практического применения, поэтому анализ темы данной работы поможет выявить и выявить основные недостатки действующего регулирования. В результате, учитывая специфику всех видов ответственности, наиболее эффективной формой ответственности для юридических лиц является административная ответственность в виде экономических санкций, что является одним из наиболее эффективных средств соразмерного наказания в наиболее оптимальные сроки для решения экологических проблем. ущерб и средства правовой защиты. Используемая методология - анализ документов, систематический анализ, сравнительный, логико-аналитический метод и методы обобщения.
\end{abstract}

Ключевые слова: юридические лица, ответственность, экологический ущерб и средства правовой защиты.

(C) The Author(s) 2021

Received date 01.05.2021

This is an open access article under

Accepted date 16.05.2021

the Creative Commons CC BY license

Published date 10.06.2021

How to cite: Perkumienè, Dalia \& Čilinskaite, Laura. Legal problems of legal entities ' liability for damages to the environment regulation. HUMANITIES STUDIES: Collection of Scientific Papers / Ed. V. Voronkova. Zaporizhzhia : Publishing house "Helvetica", 2021. 8 (85). P. 105-112.

doi: https://doi.org/10.26661/hst-2021-8-85-11

(C) Perkumienè, Dalia, Čilinskaitè, Laura, 2021 